\title{
Інформативність комп'ютерної томографії в діагностиці поєднаної туберкульозної патології
}

Ігнатьєва В.І. ${ }^{1}$, Линник М.І. ${ }^{1}$, Гуменюк Г.Л. ${ }^{2}$, Святненко В.А. ${ }^{3}$

1. ДУ «Національний інститут фтизіатрії і пульмонології ім. Ф.Г. Яновського НАМН України», м. Київ, Україна

2. Національний університет охорони здоров’я України ім. П.Л. Шупика, м. Київ, Україна

3. Національний технічний університет України «Київський політехнічний інститут ім. Ігоря Сікорського», м. Київ, Україна

Обґрунтування. Запровадження карантину з приводу COVID-19 може призвести до зниження виявлення хворих на туберкульоз, зростання захворюваності та смертності від цього захворювання. На тлі виснаження імунної системи населення дедалі частіше трапляється поєднана туберкульозна патологія, зокрема поєднання туберкульозу легень і туберкульозного отиту. Туберкульоз середнього вуха виникає як вторинний процес ухворих на дисеміновані й інші форми легеневого туберкульозу. Діагностика поєднаної патології значно утруднена, коли специфічний процес перебігає на тлі хронічної неспецифічної патології легень. У таких випадках актуальності набуває застосування додаткових методів дослідження, а саме комп'ютерної томографії (КТ) скроневих кісток та органів грудної порожнини (ОГП).

Клінічний випадок. Хвора Т., 1982 р. н., в анамнезі має всі календарні щеплення БЦЖ. Із 2008 р. спостерігається в пульмонолога з приводу бронхоектатичної хвороби нижньої частки лівої легені. Неодноразово лікувалася стаціонарно й амбулаторно. 3 березня 2018 р. спостерігається в оториноларинголога з приводу хронічного лівобічного гнійного середнього отиту. Останнє загострення було в лютому 2020 р. Виконано пункцію та шунтування барабанної порожнини. Тоді ж з'явилися загальна кволість, нежить, біль і пирхота в горлі, підвищення температури тіла до $37,5^{\circ} \mathrm{C}$, потім - кашель із гнійним мокротинням, осиплість голосу.
Отримувала декілька курсів неспецифічної антибактеріальної терапії, але без позитивного ефекту. 3 метою уточнення діагнозу та лікування направлена до Національного інституту фтизіатрії і пульмонології. Проведено КТ скроневих кісток, у ході якої виявлено ознаки лівобічного середнього отиту та мастоїдиту (рис. 1). На аудіограмі - погіршення слуху за типом слухопроведення (кістково-повітряний розрив на частоті 4000 Гц дорівнював 50 дБ). Виділення з лівого зовнішнього слухового проходу відсутні. На КТ ОГП - ознаки дисемінованого туберкульозу легень, сегментарний ателектаз нижньої частки зліва (рис. 2). Мікроскопія мокротиння: КСП не виявлено, GenXpert MTB+ RIF-. Розпочато основний курс антимікобактеріальної терапії за I категорією. Місцево - офлоксацин (вушні краплі). У результаті призначеного лікування отримано позитивну динаміку поєднаної патології (рис. 3).

Висновки. Незважаючи на своєчасне звернення по медичну допомогу, у хворої на хронічний середній отит і бронхоектатичну хворобу, що не піддавалися неспецифічній антибактеріальній терапії, не було своєчасно діагностовано туберкульоз. Проведення КТ скроневих кісток та ОГП у пацієнтів із хронічними захворюваннями легень у поєднанні з хронічним середнім отитом має високу інформативність у виявленні туберкульозного процесу й оцінки ефективності лікування.

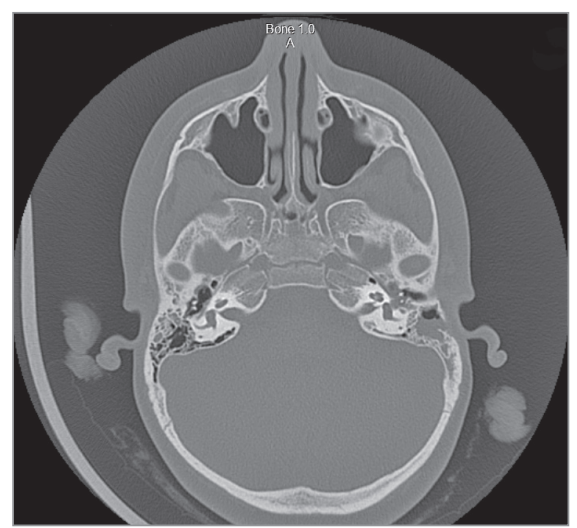

Рис. 1. КТ скроневих кісток: ознаки лівобічного середнього отиту та мастоїдиту

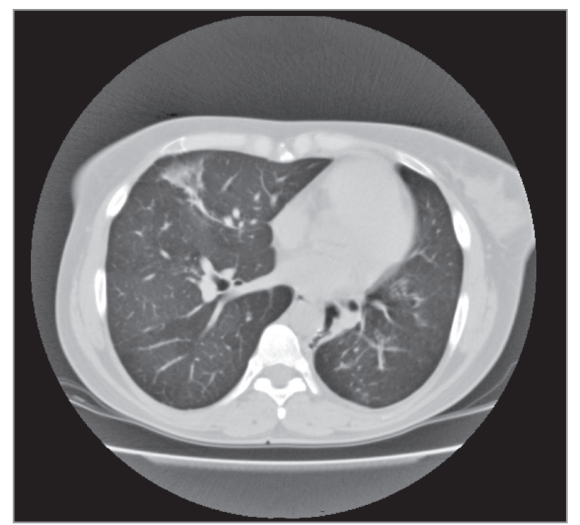

Рис. 2. КТ ОГП: ознаки дисемінованого туберкульозу легень, сегментарний ателектаз нижньої частки зліва

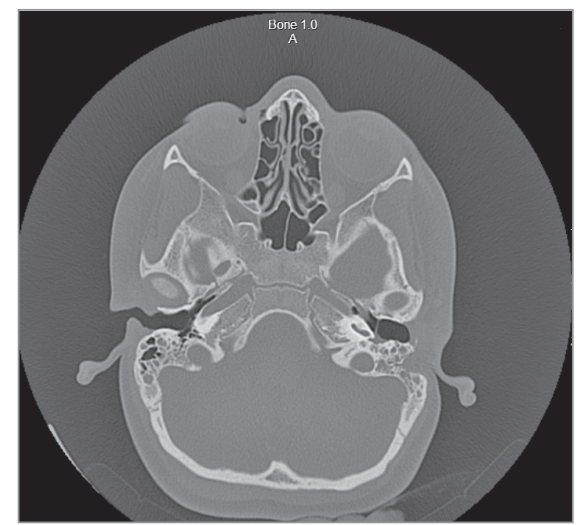

Рис. 3. КТ скроневих кісток: позитивна динаміка на тлі призначеної антимікобактеріальної терапії 